\title{
Prophetic Witness: An APPRopriate mode of PUblic Discourse IN THE DEMOCRATIC SOUTh AfricA?
}

Author:

Etienne de Villiers ${ }^{1}$

\author{
Affiliation: \\ ${ }^{1}$ Department of Dogmatics \\ and Christian Ethics, \\ University of Pretoria, \\ South Africa
}

\section{Correspondence to: Etienne de Villiers}

email:

etienne.devilliers@up.ac.za

\section{Postal address:}

Faculty of Theology,

University of Pretoria, Lynwood Road, Hatfield 0083, Pretoria, South Africa

\section{Keywords:}

Accra Declaration; biblical prophecy; democracy, inner-directed spirituality; Kairos document; mode of moral discourse

\section{Dates:}

Received: 02 Feb. 2010 Accepted: 13 July 2010 Published: 08 Oct. 2010

How to cite this article: De Villiers, E., 2010, 'Prophetic witness: An appropriate mode of public discourse in the democratic South Africa?', HTS Teologiese Studies/ Theological Studies 66(1), Art. \#797, 8 pages. DOI: 10.4102/hts.v66i1.797

This article is available at: http://www.hts.org.za

\section{Note:}

This article was initially presented as a paper at the conference on 'Prophetic witness: An appropriate mode of public discourse in democratic societies?' that was held at the University of Pretoria on 26-27 October 2009.

\section{(C) 2010. The Authors.} Licensee: OpenJournals Publishing. This work is licensed under the Creative Commons Attribution License.

\section{ABSTRACT}

The question asked in the heading was answered in this article in four steps. In the first step, an attempt was made to find an accurate account of biblical prophecy by means of a critical discussion of certain influential interpretations of it. In the second step, the extent to which biblical prophecy could serve as a model for contemporary Christians was discussed and an acceptable Christian model of prophetic witness was formulated by drawing on the views of different authors. In the third step, the impact of democracy on the prophetic witness of the church was discussed. The Dutch theologian, Gerrit de Kruijf's view that the public prophetic witness of the church is not appropriate in democratic societies was criticised and the legitimacy of certain forms of prophetic witness in such societies defended. In the final step, a number of examples of the prophetic witness that is needed in the present democratic South Africa were provided.

\section{INTRODUCTION}

An adequate answer to the question whether, and to what extent, prophetic witness still provides an appropriate mode of public discourse in the present democratic South Africa depends, in my opinion, on the answers to four more specific questions:

- What constitutes an accurate account of biblical prophecy?

- To what extent is biblical prophecy an appropriate model for contemporary Christians?

- How is giving prophetic witness today impacted upon by the context of democracy?

- Can convincing examples be provided of the prophetic witness that is needed in the present democratic South Africa?

In this article I address these four questions and then, in the conclusion, provide an answer to the question about the appropriateness of prophetic witness in the present democratic South Africa.

\section{AN ACCURATE ACCOUNT OF BIBLICAL PROPHECY}

Accounts of the distinctive features of biblical prophecy are often influenced by normative notions of prophecy already held by interpreters. These accounts also depend on the level on which the distinctive features of biblical prophecy are sought, for example, on the level of the personal characteristics of the biblical prophet, or rather on the level of the practice of biblical prophecy. I restrict myself to a discussion of two such accounts that have been quite influential:

\section{Understanding prophecy predominantly in terms of the extraordinary characteristics of the person of the prophet}

The development and increasing use of the historical-critical method in Old Testament studies at the end of the 19th century brought new insight into the distinctive role and personal characteristics of the group of religious leaders depicted as prophets in the Ancient Near East. Old Testament scholars placed special emphasis on the distinctive characteristics of the Old Testament prophets. This account of prophecy also influenced Max Weber (2005), the German sociologist who gives extensive attention to Old Testament prophecy in his studies on Die Wirtschafsethik der Weltreligionen: Das Antike Judentum (The economic ethics of world religions: Ancient Judaism) written during the first decade of the 20th century. The picture he draws of the prophets provides a fairly accurate reflection of the dominant views of the Old Testament scholars of his time and can serve here as an example. He calls the Old Testament prophets 'Sendungspropheten', that is, prophets who, in one or the other ecstatic experience, received a direct calling from Yahweh to go to his people and convey his Word to them. They acted predominantly on their own, made use of emotional and dramatic language to convey their message in a convincing way and often had to overcome great resistance (Weber 2005:631-648). The picture that Weber draws of the Old Testament prophet is, in other words, that of a heroic, charismatic, lonely and exceptional person (cf. also Otto 2005:202-212).

There is, however, strong consensus among contemporary Old Testament scholars that Old Testament prophecy should not, in the first instance, be understood in terms of the exceptional characteristics of the prophets as persons. As Reinhard Gregor Kratz (2003:41) points out in his recent book Die Propheten Israels (The prophets of Israel), it is not so much the biography of the prophets that is conveyed to us in the Old Testament, but rather their books. Central to these books are not the prophets and their actions, but the Word of God, the comprehensive plan of God for his people and the world, that is presented in them and can be known by reading them (Kratz 2003:44). In fact, the conclusion of many decades of Old Testament study is that it is impossible to isolate the original words of the inspired prophets and, for that matter, to retrieve historically accurate accounts of their personalities from the biblical texts. The message of the prophets is only given in the interpretation of different authors that were involved in editing and interpreting the books of the prophets. These anonymous co-authors 
re-interpreted the message of the prophets in order to convey what they perceived as the Word of God to the people of their own time. In the process, different generations of them rewrote the prophetic books to add their own actualised interpretation of God's Word. This means that in the prophetic books of the Old Testament we are also - if not for the most part - confronted with the prophetic message of anonymous prophetic scribes whose personal characteristics are not of any significance (see Kratz 2003:48-49).

\section{Understanding prophecy in terms of a revolutionary struggle against a particular unjust political or economic system}

Both the Kairos document of 1986 and the Accra Declaration of the World Alliance of Reformed Churches (WARC) of 2004 provide examples of such an understanding of prophecy as a particular practice; the Kairos document perhaps more clearly so than the Accra Declaration. In both typical elements of biblical prophecy are utilised, such as the reading of the signs of the time, indictment of sins and the provision of a vision of hope. In the case of the Kairos document, the move is swiftly made from biblical illustrations of these elements to social analysis in Marxist terms, in which the prevalent conflict in South Africa is described as a revolution or a civil war between oppressor and oppressed, to complete rejection of the apartheid regime - depicted as tyrannical and irreformable and therefore to be removed - to a message of hope that God, who is on the side of the oppressed in their struggle, guarantees liberation from the tyrannical apartheid regime. One of the implications drawn out in the final section of the Kairos document is that the church should also take sides unequivocally and quite simply participate in the struggle for liberation.

In the case of the Accra Declaration, references to biblical texts that illustrate the different elements of prophecy are directly linked to a particular economic system. Social analysis is provided in which the real causes of the suffering of the people and damage done to the rest of creation are identified as an unjust economic system imposed by global neoliberal capitalism and empire, a system of domination led by powerful nations to protect and defend their own interests. This world economic order is depicted as Mammon and strongly rejected because it defies God's covenant with all of creation, based on the vision of justice and peace. Probably as a result of strong differences of opinion among representatives of the member churches of WARC, the Accra Declaration does not recommend such strong revolutionary action to churches as in the case of the Kairos document, although such recommendations would have been consistent with its complete rejection of economic globalisation (cf. Bedford-Strohm 2007 for a critical discussion of the Accra Declaration).

The problem with this revolutionary interpretation of the prophetic approach is that it does not adequately reflect the biblical message on prophetic witness in its fullness and, in some respects, even goes against its general drift. It is true that the Old Testament prophets, for the most part, relate their message to the concrete situation and even to specific political crises in which Israel found itself. However, the prophetic analysis of the situation, indictment and vision of hope that form part and parcel of the prophetic message are never aimed at legitimising war or rebellion against the political enemies of Israel by demonising the enemy and guaranteeing the eventual victory over the enemy because God is on the side of Israel's political struggle. One can rather say that the Old Testament prophets radically theologise the political crises in which Israel found itself. The cause of dire situations of political oppression and exile is, for the most part, found in the unfaithfulness of the Israelites to God and to his 'torah' and in God's punishment of such unfaithfulness. The indictments against idolatry, injustice against the poor and other transgressions of God's law are therefore mostly directed against the people of Israel and their political and religious leaders. And the aim of the visions of deliverance is to give the Israelites hope by assuring them that God remains faithful in spite of their unfaithfulness and will eventually liberate them from political oppression and material deprivation.

What is of special importance in the context of this article is that biblical prophetic witness is never based on the assumption that those against whom the lamentations, indictments or threats are directed are irredeemable or irreformable. To the contrary, as a result of the fact that such lamentations, indictment or threats are mostly directed to the Israelites on the basis of their covenantal relationship with God, their main aim is precisely to appeal to the Israelites and their leaders to repent, to confess their sins and to mend their ways. In many instances this implies the need for reform: in the case of kings, reform of their unjust and oppressive policies and, in the case of the rich, reform of their exploitative actions against the poor.

With this realisation we have, in my opinion, already touched on the most important distinctive features of biblical prophecy. These features are not so much to be found in extraordinary personal characteristics of the biblical prophets, but can be gleaned from the typical prophetic message assigned by God to the leaders and/or people of Israel. Although the particular content of the prophetic message varied in different historical situations and from prophet to prophet, a number of the following elements were always part of it, (1) lamentation on the dire situation in which the people of Israel found themselves, (2) indictment of the leaders and/or the people of Israel on account of their unfaithfulness to God and his law, (3) announcement of severe punishment by God, (4) a call to repentance and (5) a message of hope that God will in future provide deliverance and bring about a new situation of peace and justice if Israel remains faithful to God. I guess that one would be justified to say that the distinctive and wholly religious practice of the biblical prophets entailed delivering messages that consisted of at least a number of these elements.

\section{BIBLICAL PROPHECY AS MODEL FOR CONTEMPORARY CHRISTIANS}

In answering the question, 'To what extent is biblical prophecy a model to contemporary Christians?', we have to take into account that both mainstream Christianity and Judaism accept that full-blown biblical prophecy, which I have just described, ended in biblical times. Nevertheless, this does not take away from the fact that, in later periods, both in Christianity and in Judaism, individuals sometimes claimed to be prophets in the full biblical sense of the word. ${ }^{1}$ These claims were, however, denied for the most part by both mainline Christianity and Judaism.

In spite of the denial that biblical prophets can, in all respects be imitated in post-biblical times, mainline Christianity and Judaism never denied that biblical prophecy can, in some respects, be models to believers of other ages. In the history of the Christianity and Judaism, a number of attempts were made to elucidate in which respects biblical prophecy can and should serve as a model to believers. As in the case of the identification of the distinctive features of biblical prophecy, the respects in which biblical prophecy serve as a model were found on different levels.

Max Weber (2005) was impressed by the personal characteristic of charismatic leadership of biblical prophets and was of the opinion that they could as such serve as a model to contemporary political leaders. Apart from the fact that personal characteristics

1.In the history of Christianity, the Italian monk, Girolamo Savonarola (1452-1498), is an example of someone who took on the role of biblical prophet in his own time in Florence (cf. Christelike Encyclopedie, Deel VI: 47-48). Similarly, in the history of Florence (c. Chriselike Encyclopedie, Deel VI: 47-48). Silarly, in the history of Judaism, Abraham Abalafia claimed in Sicily in 1290 to be a prophet like those of Ancient Israel (cf. Walzer, Lorberbaum \& Zohar 2004:235-243). 
are hardly central to biblical prophecy, the problem is also that the biblical prophets did not play any role in political leadership, but, at the most, a very specific religious leadership role within a specific historical context. It is difficult to see how the role they played as charismatic religious leaders in Ancient Israel can serve as a model to contemporary political leaders.

In the Kairos document and the Accra Declaration, it is the aspect of revolutionary resistance against unjust political and economic systems as part of the practice of biblical prophecy that is elevated to the status of model for contemporary Christians. I have already alluded to the fact that the revolutionary interpretation of prophetic practice hardly reflects the purely religious nature of the message and actions of Old Testament prophets. Apart from that, though, if we had to accept this interpretation of prophetic practice as model, it would only be applicable in extreme situations of political oppression and economic exploitation in which the complete rejection of the existing political or economic system and revolutionary action are the only options left, even for Christians. It would hardly be applicable in the contemporary democratic South Africa. To propagate as prophetic witness the radical rejection of the present government, the denouncement of its reform measures as mere cosmetic changes, and the call to revolutionary action against it just would not make any sense (De Villiers 2009:191). The main problem with this interpretation of biblical prophecy as model is that it does not make any allowance for a reformist approach. If prophetic attention for the concrete situation is reduced to the exposure of particular oppressive and unjust political and economic systems, if prophetic criticism is reduced to the complete rejection of such systems and the prophetic message of hope is reduced to the guarantee that they will be overthrown because God is on the side of those who struggle against them, the reformist approach has to be rejected as hopelessly inadequate.

While the Kairos document and the Accra Declaration rather narrowly see the practice of biblical prophecy as model of revolutionary resistance for Christians, the well-known philosopher, Michael Walzer (1987), views it as model of social criticism not only for Judaist and Christian believers, but for all people. He believes that Old Testament prophecy is 'the standard form of social criticism' (1987:87) and that the prophets can even be regarded as 'the inventors of the practice of social criticism' (1987:71). With this acknowledgement, Walzer is not thinking about prophets, such as Jonah, who came from outside the community at Nineveh to announce God's judgement and, as such, provide an example of a less than ideal disconnected social criticism, but, rather, he is referencing prophets such as Amos, who provide examples of the ideal of connected social criticism (1987:37-39, 2002:xii). Walzer (1987) therefore disagrees with Martin Buber, who calls the Jonah story a 'paradigm of the prophetic nature and task' (Buber 1960:104), further arguing that

[t]he paradigmatic task of the prophets is to judge the people's relations with one another (and with 'their' God), to judge the internal character of their society, which is exactly what Jonah does not do.

(Walzer 1987:80)

The prophecy of Amos, and that of those like him, is social criticism in the ideal sense because it challenges the leaders, the conventions and the ritual practices of a particular society and because it does so in the name of values that are recognised and shared in that same society. When we analyse the work of later social critics, we can recognise in their work the same intellectual structure as in the prophetic practice of someone such as Amos, that is:

$[T]$ he identification of public announcements and respectable opinion as hypocritical, the attack upon actual behaviour and institutional arrangements, the search for core values (to which hypocricy is always a clue), the demand for an everyday life in accordance with the core. The critic begins with revulsion and ends with affirmation...

(Walzer 1987:87)
One can appreciate the original way in which Walzer draws valuable insights from an analysis of the practice of Old Testament prophecy for the practice of social criticism in our day. He can, however, only do it by completely filtering out the very distinctive religious content of prophetic practice as model. The faithful relationship of the people of Israel to God and elements like the pronouncement of God's wrath and judgement and the call to repentance are completely ignored. However, from a Christian perspective, the sharp distinction that Walzer makes between the practice of prophecy and the message of the prophets, and his elevation of only the practice to the status of model, is unacceptable (see Walzer 1987:92). As contemporary Christians, we also have to explore the possibility that aspects of the message of the prophets can be interpreted in such a way that we can retain its normativity. That does not mean that we have nothing to learn from Walzer's views on social criticism. His emphasis on the importance of the 'connected critic' (Walzer 2002:xx) and the necessity to relate to values shared by the community or society that is criticised, should be taken seriously by the contemporary Christian prophet.

In the article so far, two respects in which biblical prophecy has been promulgated as model have been discussed: firstly, certain personal characteristics of the prophet and, secondly, particular elements of the practice of prophecy as normative. The Christian ethicist, James Gustafson, identifies a different respect in which biblical prophecy can serve as model, namely as a legitimate mode of moral discourse, to be distinguished from three other legitimate modes: narrative, ethical and policy.

According to Gustafson (1988) two aspects distinguish the prophetic mode from the others. Firstly, the prophetic mode takes the form of moral or religious indictments, which usually, though not always, address what the prophet perceives to be the root of religious, moral or social waywardness. They do not analyse possible solutions to quite particular problems, but rather get to the roots of systemic evils that pervade institutions and cultures, or the actions and behaviour of individual persons. 'Prophetic discourse generally looks for a demon, a power, or source, which presumably underlies all the numerous signs of what is wrong in society' (Gustafson 1988:11). The other feature of prophetic indictments is that the language and symbols that are used to make them are directed to the 'heart', as well as the 'head'. The prophet usually does not make an argument, but rather demonstrates, shows and tells (Gustafson 1988:11).

Secondly, the prophetic mode portrays an alluring utopia or vision of the future, of possibilities for life in the world in which the forms of strife and suffering we experience are overcome. To quote Gustafson (1988):

The utopian allure is, we are told over and over, not only important, but necessary. It provides hope in the midst of despair, it lifts the eyes and the aspirations beyond what hard realists see as possible to the possibilities that lie beyond.

(Gustafson 1988:14)

Gustafson is of the opinion that prophetic moral discourse locates the problems of humanity at deeper levels than ethical and policy discourse do and thus stirs our moral sentiments. This is, however, not sufficient, because it involves a necessary simplification of very complex problems and issues. Gustafson (1988) argues:

If prophetic discourse ... is judged to be the sole and proper mode of moral discourse by Christian leaders ... a huge barrier is created between prophetic voices and those that speak in more precise and rational modes of argumentation, and ... those whose callings require of them to make choices within complex institutions and in difficult policy issues.

(Gustafson 1988:17)

The mode of moral discourse that, according to Gustafson's description, differs the most from the prophetic mode is the policy mode. By 'policy discourse', Gustafson means the 
writings which seek to recommend or prescribe quite particular courses of action about specific issues (Gustafson 1988:46). He highlights two features of policy discourse, the first of which is that this discourse is not conducted by external observers, but by the persons who have the responsibility to make choices and to carry out the actions that are required by those choices. It is, in other words, discourse by the agents who are accountable for their subsequent actions and outcomes. The second feature is the particularity of conditions within which policy is developed. These conditions both limit the possibilities of action and enable them.

I am of the opinion that Gustafson (1988:52-53) helps us forward in more than one way. First of all, he convincingly demonstrates that there is not only one legitimate type of moral discourse. It is also not the case that there is a hierarchy of modes of moral discourse and that one particular mode is more authentically moral than the others. This is important, especially in light of the tendency to regard the prophetic mode as the highest, if not the only, authentically Christian mode of moral discourse. Secondly, Gustafson also convincingly argues that not one of these modes of moral discourse is all-sufficient, but that they complement and correct one another and are therefore all indispensable.

However, in the context of the present investigation one also has to point out certain shortcomings of Gustafson's distinction which is a purely formal one that obliges us to depict certain moral discourse - whether religious of non-religious, or even unacceptable from our own ethical perspective - as prophetic. In terms of the features of the prophetic mode of moral discourse that Gustafson identifies, for example, one cannot but depict as prophetic the denouncement of the liberation struggle in strong religious language by certain religious organisations with government links in the previous political dispensation. They denounced the liberation movement as communist and identified communism as the root cause of everything that went wrong in South Africa. From a contemporary Christian perspective, the depiction of such an approach as prophetic seems hardly appropriate. Again, one can ask whether any attempt to promulgate prophecy as a model for contemporary society that does not take into account the message of the biblical prophets with its particular religious content, ought to have the full support of Christians. The only way to avoid inappropriate attempts to promulgate biblical prophecy as a model, would, in my opinion, be to take recourse to substantive criteria derived from the message of the biblical prophets.

However, as Kratz (2003) emphasises in his recent book on the prophets of Israel, one does not really bear witness to the message of the prophets by applying it to our own time in a direct and literal way. The books of the prophets are the products of a process of renewed re-interpretation and re-actualisation of the plan of God as unfolded in previous written versions of the prophetic message. The prophetic books invite the readers to do the same thing in their own time. We should therefore be careful to derive in too simplistic a way substantive criteria from the message of the biblical prophets and to hold these criteria up to contemporary Christians as normative (Kratz 2003:45).

Walter Brueggemann, in his book The prophetic imagination (2001), placed a similar emphasis on the text of the prophetic books. In the preface of the revised edition of the book, Brueggemann (2001) also takes issue with a one-sided emphasis on the personality of the prophet or the confrontational nature of prophetic witness. He stresses that prophetic texts 'are acts of imagination that offer and purpose 'alternative worlds' (Brueggemann 2001:x). On the basis of this understanding of the prophetic texts he explores in his book the hypothesis: 'The task of prophetic ministry is to nurture, nourish, and evoke a consciousness and perception alternative to the consciousness and perception of the dominant culture around us' (Brueggemann 2001:3). His interpretation of the central message of the prophetic books is that this alternative consciousness points towards an alternative religion of the freedom of God and an alternative politics of justice and compassion. It serves, on the one hand, to criticise by dismantling the dominant consciousness in the light of present day interpretation of what true religion, justice and compassion according to the prophetic texts imply. On the other hand, it serves to energise persons and communities by its promise of another time and situation, an alternative world characterised by true worship of God and by justice and compassion, toward which the community of faith may move (Brueggemann 2001:3-9).

In my opinion a combination of the views of Walzer (1987), Gustafson (1988) and Brueggemann (2001) can provide us with an acceptable Christian model of prophetic witness. Prophetic witness should be practiced as social criticism and understood as a connected criticism of a particular community or society, based on values that are shared by those who are criticised. To qualify as Christian, this prophetic witness should take as point of departure core religious and moral values that form part and parcel of the Bible and the Christian tradition. To qualify as prophetic, this Christian witness should transfigure these core Christian values imaginatively into a vision of alternative communal life that both serves to fundamentally criticise existing communal life and optimally inspire efforts to realise the vision in a particular community or society.

\section{THE IMPACT OF DEMOCRACY ON THE PROPHETIC WITNESS OF THE CHURCH}

If we take this model of Christian prophetic witness as point of departure we are, of course, immediately confronted with a quandary when the context in which it has to be practiced is a contemporary democracy with a predominantly liberal constitution like South Africa. All contemporary democratic societies with a liberal constitution are, in a stronger or weaker sense of the word, 'secular' societies. In other words, the constitutions of these societies uphold to a certain extent the separation of religion and the state. This poses the serious question: Does it really make sense for Christian churches to practice prophetic witness in such a society?

The Dutch Reformed theologian Gerrit de Kruijf, in his book Waakzaam en nuchter: Over Christelijke ethiek in een democratie (Vigilant and level-headed: On Christian ethics in a democracy) (1994), also grapples with this problem. His main discussion partner is the Swiss Reformed theologian Karl Barth. De Kruijf (1994:40-52, 236-240). Comes to the conclusion that the influential Barthian approach of prophetic Christian witness in public on political and economic matters is not appropriate in contemporary liberal democracies. He does not deny that there may come a moment that faith in Christ cannot tolerate developments within a particular liberal democratic state and that faithfulness to Christ and political disobedience may coincide. Such a 'status confessionis' is, however, something extraordinary (De Kruijf 1994:182). In normal circumstances, the witness or prophetic approach is incompatible with a liberal democracy because it insists that the Christian view should be the basis of policy and legislation and that other views need not be taken into account. In De Kruijf's (1994) opinion the prophetic approach still presupposes a theocratic view of society that has become obsolete in our time. In addition, this approach is not constructive, because the church should know in advance that its prophetic Christian witness cannot be accepted in plural democracies as the basis for policy and legislation. If churches and individual Christians want to contribute responsibly to consensus and policy formation, then they should not make prophetic pronouncements on societal issues on the basis of their own 'thick' or strong Christian values, but should rather participate in public discussions on the basis of the 'thin' cultural values shared by all in plural societies (De Kruijf 1994:188, 195). ${ }^{2}$

2.For the distinction between 'thick' and 'thin', as used with regard to morality and ethics, see Walzer (1994:xi, footnote 1). Here, Walzer utilises the term 'thick' to point to a kind of moral argument that is 'richly referential, culturally resonant, locked into to a kind of mora argument that is ' . 'Thin' is simply the contrasting term. 
The following three subsections each centre on a response to De Kruijf's argument above:

\section{Prophetic witness should, in the first instance, be directed to the Christian community}

I am of the opinion that we can concur with De Kruif (1994) to the extent that Christian prophetic witness should not, in the first instance, be directed to the broader society or to the state. The most appropriate sphere in which to practice Christian prophetic witness today still remains the community of believers, that is, the church. This community shares the Christian values on which Christian prophetic witness is based and its members should therefore be able to relate to these values and the transfiguration of these values in a vision of communal life that is both critical and inspiring. However, this community also experiences enormous pressures today to compromise its Christian values and is therefore often in serious need of strong prophetic witness. For example, in its present form, the free market system exerts such a dominant influence on contemporary societies that not only individual Christians, but also church denominations, often inadvertently allow free market values, such as materialism, greed, consumerism and competition, to guide their personal and institutional life. In the process, not only traditional Christian moral values, but even the Christian gospel is compromised, especially when it is transformed into a prosperity gospel. Should Christian prophetic witness today not, in the first instance, be directed against such compromising of the Christian gospel? And should it not provide to contemporary Christians an inspiring vision of alternative Christian life in the church and in broader society?

Individual Christians and churches do not only have the responsibility to provide prophetic witness or to practice social criticism in regard to their own Christian community. They also have the responsibility to practice social criticism with regard to the national societies and the world society in which they live, not only because the value systems that are dominant there can have a negative influence on the Christian community, but also because they are called by God to serve the coming of his Kingdom in this world. This social criticism, including the formulation of visions of a good society that form part of it, should first of all be done in terms of the strong Christian values that they share. Not only are the strong moral and religious beliefs of a person or a community the most conspicuous point of departure for social criticism, but, if this is done, it increases the chances that such a person or community can make a unique and valuable contribution to the broader society. The challenges involved in providing such social criticism in a thorough and responsible way, of course, often outstrip the capabilities of individual Christians or even congregations on their own. Social criticism is often better conducted in an organised way within a particular church denomination or ecumenical organisation.

If I understand him correctly, De Kruijf (1994) has reservations about official reports by church denominations and ecumenical organisations on societal issues. Although he is of the opinion that the relativising of the outwardly directed voice of the church on societal issues must be accompanied by the stimulation of thinking within the Christian congregation on the meaning of faith for the public life, he fears that official church reports are, for the most part, presented and experienced as authorative guidance that has to be followed by church members. In his opinion, the chances are good that such authorative guidance on societal issues will stifle the critical thinking of individual members and their responsibility to play an active role as citizens in society (De Kruijf 1994:241-246). That such a risk exists cannot be denied. Church reports on societal issues have, in the past, in the case of South African churches, often played such a stifling role. There are, however, also in the South African context, abundant examples of church and ecumenical reports and declarations that stimulated the critical thinking of individual
Christians and encouraged them to be more responsible citizens. Much depends on how church and ecumenical reports on societal issues are compiled.

\section{Prophetic witness on public issues in democratic societies, based on Christian values, can be appropriate}

De Kruijf (1994) is of the opinion that Christian prophetic witness in the public sphere is not appropriate in any liberal democratic society. I wonder whether such a judgement is wholly justified. First of all, the separation of religion and the state that is required in different democratic societies is not always of an equally hard nature. In contrast to the constitutions of the United States of America and France, the separation of religion and state that is required by the new South African constitution is rather a soft one. Section 15 of the South African constitution stipulates that religious observances are allowed in state institutions on a fair basis. Some room is given for religions to play a public role and exert a public influence.

However, what is more important is that not all democratic societies are secularised to the same extent. It is probably true that in highly secularised societies with a low percentage of professing Christian believers and an even lower percentage of active churchgoers, Christian prophetic witness on public issues would cause some minor irritation, but would, for the most part, be completely ignored. It is different in a new democratic society like South Africa, which is highly religious in comparison to European societies and has a fairly high percentage of professing Christian believers. The majority of South Africans are not only fully capable of understanding Christian language and arguments, but are also susceptible to it. As an African society, South Africa also has not undergone such a strong process of privatisation of religion, as is the case in Europe, because some of the historical factors that contributed to this process in Europe have been absent (cf. De Villiers 2005:530-533). One can therefore concur with the sociologist José Casanova (1994), who asserts that the public role of religion as part of civil society may be accepted as compatible with democratic institutions, especially in societies such as South Africa, and may even be allowed to contribute to the humanising of society (Casanova 1994:39). That such a conclusion is not too farfetched is illustrated by the wide acceptance of both Archbishop Desmond Tutu's explicitly Christian prophetic witness on reconciliation as Chairperson of the Truth and Reconciliation Commission and of former President Thabo Mbeki's strong denouncement of the prevalent greed in the South African society in the Fourth Annual Nelson Mandela Lecture at the University of the Witwatersrand University in 2006, in which he made explicit use of biblical citations and prophetic terminology.

\section{Social criticism of government legislation and policy based on shared values can also be regarded as prophetic witness}

I fully concur with De Kruijf's (1994) view that Christian churches cannot expect the government of a liberal democracy to base its legislation and policies on their Christian prophetic witness in terms of strong or 'thick' Christian values. Legislation - for example on abortion - has to allow different-minded groups and individuals to act in accordance with their own consciences. Churches therefore, as De Kruijf proposes, have to think twice when it comes to social criticism of existing government legislation and policies and lobbying for new legislation and policies. They can and should, in the first instance, formulate their own Christian views on legislation and policies, based on strong Christian values. If they want to effectively influence government policies and legislation they will also have, in the second instance, to base their views on arguments and values that can be accepted by non-Christians. De Kruijf (1994:195-209) 
expresses the opinion that, in the European context, it is possible to base such arguments on a number of cultural values that are shared by most Europeans. One may ask whether De Kruijf is, today, still as confident that such shared cultural values can be identified, after it has become clear that many of the increasing number of immigrants from especially Muslim countries prefer to retain their traditional values and are not willing to be fully integrated in European societies. One can also ask whether it would be possible to identify, in the South African context, a number of such cultural values that are shared by most South Africans. In our context it would probably be better to base arguments regarding government legislation and policies in the public sphere on the bill of rights contained in the South African constitution.

I would like to pose the question of whether Christians who are involved in the public sphere in such social criticism of government legislation and policy have really abandoned the practice of prophetic witness as De Kruijf seems to suggest. I concede that, from a Christian perspective, prophetic witness in the full or the strong sense of the word has to be based on strong Christian values. However, why can we not say that Christians who practice social criticism of government legislation and policy on the basis of 'thin' shared morality are also involved in prophetic witness, be it prophetic witness in a weaker sense of the word? If they are ultimately motivated in doing this by their strong Christian beliefs and aim to contribute to a better society that is more in accordance with their Christian view of a good society, there is, in my opinion, no reason to deny that they are also involved in prophetic witness. After all, Amos prophesied powerfully against his fellow Israelites and also criticised other nations. In his social criticism of these nations he does not refer to the 'torah', but limits himself to violations of some sort of international law (cf. Walzer 1989:91-94). The fact that Amos based his social criticism of the other nations on some minimal code does not prevent us from saying that he also prophesied against those nations.

\section{EXAMPLES OF PROPHETIC WITNESS NEEDED IN THE PRESENT DEMOCRATIC SOUTH AFRICA}

In the previous paragraph three forms of prophetic witness that has the potential to impact the public sphere and should be regarded as still appropriate in the democratic South Africa have been identified: prophetic witness directed at the Christian community, prophetic witness on public issues based on Christian values, prophetic witness on government legislation and policy based on shared values. Now, I briefly discuss examples of these three forms of prophetic witness:

\section{Prophetic witness against the inward-directed spirituality of South African churches}

The form of public witness that most authentically reflects biblical prophecy is social criticism, based on strong Christian values, of aspects of the life of the Christian community that impact negatively on the broader society. In my opinion, an aspect of church life in the present South Africa against which strong prophetic witness is needed, is the tendency in many denominations and congregations to move away from an outward-directed spirituality in which life in the broader society features, to a narrow and one-sided inner-directed spirituality, with an almost exclusive emphasis on the personal and communal life of Christians. The emphasis in the ministry of many congregations tends to be increasingly on catering for the personal and emotional needs of the members themselves and on securing the future survival of congregations. In other words, the priestly aspect of ministry (the comforting and healing of the members) is emphasised, while the kingly aspect (the encouraging and training of members to live a holy life in all life spheres) and the prophetic aspect (contributing by means of critical involvement to the renewal of society) are, for the most part, neglected.

Prophetic witness against this narrow inner-directed spirituality is urgently needed because this spirituality filters out essential aspects of the Christian message and, as a result, individual Christians and churches do not play an optimal role in alleviating the almost overwhelming material and emotional need in the South African society. Social criticism should, however, also investigate the factors contributing to such an inner-directed spirituality. Questions such as the following should be asked: What are the views and attitudes of church members contributing to such an inner-directed spirituality? Do these views and attitudes stand the test of fundamental Christian moral values?

I do not have first-hand knowledge of the factors that contribute to an inner-directed spirituality in churches other than the Afrikaans-speaking churches. I therefore restrict myself to an analysis of some of the contributing attitudes in the Afrikaans churches. In my opinion, the unwillingness of many members of the Afrikaans churches to become constructively involved in the alleviation of societal problems is, to a large extent, based on the extremely negative view they have of what is happening in the South African society (cf. De Villiers 2008:375-380). Many members of these churches have taken the defeatist, even apocalyptic, view that the South African society is inevitably heading for collapse. This view can be partly explained by the traumatic experiences of violent crime to which some of the members have been exposed. However, the 'glasses' they wear when looking at the transformation policies of the government, such as land reform and affirmative action, also contribute to this negative view. In other words, the presuppositions of church members in regard to these policies negatively affect the way in which they interpret such policies and their implementation. There is a deep-seated and long-standing conviction among Afrikaners that if they do not have political control of the country they will inevitably be oppressed by the Black majority. ${ }^{3}$ They experience the transformation policies of the government as an affirmation of this conviction. As a result, many Afrikaners view themselves as helpless victims. Another deep-seated prejudice that still prevails among many members of the Afrikaans churches is racial prejudice. As a result, they experience the increase in crime in South Africa and the lack of governmental service delivery as additional proof of the inherent incompetence of Black people. Looking at the South African society through the lenses of these deep-seated prejudices inevitably results in many members of the Afrikaans churches harbouring strong feelings of being seriously threatened by what is happening in society.

It is these negative views and attitudes of many members of the Afrikaans churches that, in my opinion, directly contribute to the prevalent inner-directed spirituality in these churches. Overcoming the inner-directed spirituality in the Afrikaans churches would inevitably also involve addressing these negative views and attitudes in both a prophetic and a pastoral way.

\section{Prophetic witness on the neglect of absolutely poor people in South Africa based on the prefential option for the poor}

Another form of prophetic witness that could be appropriate and effective in democratic societies with a high percentage

\footnotetext{
3.Cf., for example, the pronouncements of the Voortrekker Coenraad Scheepers in 1852: '[Whites] and blacks cannot live together, unless the black man is in a state of subjection to the white' (cited in Giliomee 2003:181) and of Hendrik Verwoerd in 1948 , in which he referred to South Africa as 'a white man's country where he must remain the master' (cited in Giliomee 2003:279).
} 
of professing Christians is social criticism in the public sphere on certain issues expressed in Christian language and based on Christian values. Such social criticism could be appropriate when the purpose is not so much to lobby for specific legislation, but rather to evoke a strong public response to morally negative tendencies in political or public life. The Christian moral values on which such social criticism is based should preferably be moral values that have been widely accepted in broader society.

In the case of South Africa, an example of such Christian prophetic witness that is dearly needed is social criticism of the serious neglect of the need of the unacceptable high percentage of absolutely poor people in South Africa. The Christian moral value of special care for the poor or, to phrase it more strongly, the preferential option for the poor, has been widely accepted in South Africa as a result of the influence of liberation theology. It also overlaps with socialist values aimed at improving the situation of the worker class that have been influential in the liberation movement.

Social criticism regarding the neglect of the needs of the poor should be directed at both the private and the public sector. However, at this point of time there is an urgent need to criticise the government's neglect of the poor. The ANC government openly professes that the improvement of the plight of the poor is one of its priorities. Nevertheless, in spite of many commendable initiatives regarding the poor, one has to say that the government is, in more than one respect, letting the poor down. First of all, the failure of service delivery, especially at a local level and in the case of many municipalities, impacts most seriously on poor people. Secondly, it seems that many politicians, in spite of their professed solidarity with the poor, are more interested in enriching themselves once they are elected, by exploiting the available public resources, than in improving the plight of the poor. And thirdly, it becomes increasingly clear that an alarmingly high number of politicians and government officials are - in an effort to become rich as soon as possible willing to cross the line of immoral behaviour and become involved in corruption.

\section{Prophetic witness against the anti-democratic tendencies in the South African society based on the shared values of the constitution}

A third, weaker form of prophetic witness preferably practiced by individual Christians that could be appropriate in democratic societies is social criticism in the public sphere based on 'thin' moral and legal values also shared by non-Christians. This form of prophetic witness is especially appropriate when specific government legislation or policy is criticised or lobbied for. It is also appropriate when constitutional democracy itself, or specific institutions within constitutional democracy are under threat. In my opinion, we are now at a point in time in the South African society when it becomes increasingly clear that some institutions within our democracy and, to a certain extent, constitutional democracy itself, are put under pressure. Strong social criticism is needed against these anti-democratic tendencies.

In a well-functioning constitutional democracy, strong separation between the legislative, executive and judicial powers in government is maintained. It is especially important that those who are in charge of the judicial branch of government should be allowed to operate independently. The reason behind this necessity is that politicians of the governing party or parties in charge of the legislative branch are constantly faced with the temptation to sidestep the legal procedures and safeguards built into the constitution in order to push through legislation that serve their own interests or expand their own political power. During the last two years there have been a number of disturbing signs that the Zuma-led ANC government does not shy away from putting pressure on the judicial branch to withhold itself from the prosecution of influential ANC members and from interfering in appointment processes within the judicial branch.
A related disturbing tendency in South African political life at the moment is the growing intolerance exhibited by political parties over against their political opponents. Political parties tend to increasingly and indiscriminately denounce the views and actions of their political opponents in highly emotional, pejorative language and tend to respond to criticism directed against their own views and actions by discrediting the person who expressed the criticism, occasionally also playing the race card, instead of responding to their criticism in a dispassionate and reasonable way. In my opinion, constitutional democracy itself will increasingly come under threat if the tendency to undermine transparent public debate on political issues, which is one of the pillars of constitutional democracy, is allowed to continue unabatedly.

Although it is not only the ruling political party that is exhibiting political intolerance at the moment, it has the potential to do much more damage to the fabric and spirit of constitutional democracy than the other political parties. It has the political power at its disposal to effectively stifle criticism of its policies and actions and to punish individuals and institutions that are, in its opinion, too outspoken in their criticism. The ruling party in the previous political dispensation provides ample proof of the repression that can result from extreme intolerance of criticism expressed against government policies and actions.

Individual Christians and churches are, of course, faced with serious questions in this regard, for example: Are they justified, from a Christian perspective, to practice prophetic witness against intolerance in political life? Should they be champions of democratic rights, such as freedom of speech and press freedom and the democratic separation of the legislative, executive and judicial powers of government? They can only give credible answers to these questions if they have already done what De Kruijf recommends, namely to first of all formulate their own Christian views on constitutional democracy and its institutions. Maybe it is time for church denominations and ecumenical organisations that have not already gone through such an exercise to do just that, in order to assist their members in fulfilling their prophetic responsibility with regard to political life in South Africa. For there may just be greater need in our society for such prophetic witness in future.

\section{CONCLUSION}

In an attempt to answer the question whether, and to what extent, prophetic witness still provides an appropriate mode of public discourse in the present South Africa, I have discussed in this article different views on the distinctive features of Biblical prophecy, several proposals on how Biblical prophecy can still be a model for contemporary Christians and different forms prophetic witness can take on in democratic societies. I have come to the conclusion that prophetic witness still provides an appropriate mode of public discourse in democratic societies such as South Africa and in the final section also provided examples of how prophetic witness can function in the South African context.

\section{REFERENCES}

Bedford-Strohm, H., 2007, 'Public theology and the global economy: Ecumenical thinking between fundamental criticism and reform', Nederduits Gereformeerde Teologiese Tydskrif 48(1\&2), 8-24.

Brueggemann, W., 2001, The prophetic imagination, 2nd edn., Fortress Press, Minneapolis.

Buber, M., 1960, The prophetic faith, Harper and Brothers, New York.

Casasnova, J., 1994, Public religions in the modern world, University of Chicago Press, Chicago.

De Kruijf, G.C., 1994, Waakzaam en nuchter: Over christelijke ethiek in een democratie [Vigilant and level-headed: On Christian ethics in a democracyl, Ten Have, Baarn. 
De Villiers, D.E., 2005, 'The vocation of the Reformed ethicist in the present South African society', Scriptura 89, 521-535.

De Villiers, D.E., 2008, 'Kan die NG Kerk nog 'n konstruktiewe rol in die Suid-Afrikaanse samelewing speel? [Can the Dutch Reformed Church still play a constructive role in the South African society?]', Verbum et Ecclesia 29(2), 368-386.

De Villiers, D.E., 2009, 'Wat beteken profetiese getuienis in die nuwe politieke bedeling? [What does prophetic witness entail in the new political dispensation?]', in E. Conradie \& C. Lombard (eds.), Discerning God's justice in church, society and academy: Festschrift for Jaap Durand, pp. 191-192, SUN Press, Stellenbosch.

Giliomee, H., 2003, The Afrikaners: Biography of a people, Tafelberg, Cape Town.

Grosheide, F.W. \& Van Itterzoon, G.P. (eds.), 1961, Christelijke Encyclopedie, Deel VI [Christian Encyclopedia, Part VI], J.H. Kok N.V., Kampen.

Gustafson, J., 1988, Varieties of moral discourse: Prophetic, narrative, ethical and policy, Calvin College and Seminary Library, Grand Rapids.

Kairos Theologians, 1986, The Kairos document: Challenge to the church: A theological comment on the political crisis in South Africa, Skotaville, Braamfontein.
Kratz, R.G., 2003, Die Propheten Israels [The prophets of Israel], Beck, Munich.

Otto, E., 2005, 'Die hebräische Prophetie bei Max Weber, Ernst Troeltsch und Hermann Cohen: Ein Diskurs im Weltkrieg zur christlich-jüdischen Kultursynthese [The views of Max Weber, Ernst Troeltsch and Hermann Cohen on the Hebrew prophets: A discussion during the World War on the Christian-Jewish cultural synthesis]', in W. Schluchter \& F.W. Graf (Hrsg.), Asketischer Protestantismus und der 'Geist' des modernen Kapitalismus: Max Weber und Ernst Troeltsch, pp. 201-255, Mohr Siebeck, Tübingen.

Walzer, M., 1987, Interpretation and social criticism, Harvard University Press, Cambridge.

Walzer, M., 1994, Thick and thin: Moral argument at home and abroad, Notre Dame University Press, Notre Dame.

Walzer, M., 2002, The company of critics: Social criticism and political commitment in the twentieth century, Basic Books, New York.

Walzer, M., Lorberbaum, M. \& Zohar, N. (eds.), 2000, The Jewish political tradition, vol. 1, Authority, Yale University Press, New Haven.

Weber, M., 2005, Die Wirtschaftsethik der Weltreligionen: Das Antike Judentum [The economic ethics of the world religions: Ancient Judaism], Mohr Siebeck, Tübingen.

World Alliance of Reformed Churches (WARC), 2004, Covenanting for justice in the economy and the earth, WARC, Accra. 